\title{
ALJABAR LINTASAN LEAVITT SEMIPRIMA
}

\author{
Ningrum Astriawati \\ Program Studi Teknika, Akademi Maritim Yogyakarta \\ astriamath@gmail.com
}

\begin{abstract}
ABSTRAK.
Suatu graf dapat direpresentasikan sebagai aljabar lintasan dan jika graf tersebut diperluas dapat didefinisikan suatu aljabar lintasan Leavitt, yang pada kenyataannya merupakan Z-aljabar bertingkat. Dalam tulisan ini akan dibahas mengenai sifat semiprima pada aljabar lintasan dan aljabar lintasan Leavitt yang berlaku dalam sebarang graf. Serta menyelidiki kaitan antara semiprima pada aljabar lintasan dengan semiprima pada aljabar lintasan Leavitt.
\end{abstract}

KATA KUNCI: Graf Berarah, Aljabar Lintasan, Aljabar Lintasan Leavitt, Aljabar Linta-san Leavitt Semiprima.

\section{PENDAHULUAN}

Graf merupakan objek kombinatorial yang terdiri atas dua himpunan yaitu himpunan titik (vertex) dan himpunan garis (edge) yang dilengkapi dengan suatu pemetaan. Pemetaan disini adalah pemetaan dari himpunan garis ke himpunan titik, yang masingmasing daerah hasilnya disebut sebagai sumber/asal (source) dan ujung/target (range) dari suatu garis dalam graf. Me-nurut Assem (2006)[1] graf seperti ini disebut sebagai graf berarah(quiver).

Selanjutnya dengan mendefinisikan operasi perkalian sebagai operasi kompo-sisi pada himpunan semua lintasan dalam graf, himpunan ini mempunyai struktur semigrup. Sehingga untuk sebarang lapangan $K$ dan graf $E$ dapat didefinisikan suatu $K$-aljabar yang disebut dengan aljabar lintasan (path algebra) atas lapangan $K$ pada $E$ yang memiliki basis himpunan semua lintasan yang ada pada graf tersebut. Dengan kata lain, aljabar lintasan merupakan aljabar atas lapangan dengan basis himpunan semua lintasan yang ada pada graf. Dalam hal ini graf bukan sebagai objek kombinatorial lagi, akan tetapi graf dipandang secara aljabar.

Selain itu graf dapat diperluas sehi-ngga terbentuk graf baru yang disebut sebaai graf perluasan (extended graf). Ide perluasan ini dilakukan oleh Leavitt yaitu dengan menambahkan garis yang berlawanan arah dengan garis nyata (real edge) pada graf. Setiap garis nyata pada graf akan berpasangan dengan garis baru yang 
dibentuk, yang kemudian disebut sebagai garis hantu (ghost edge). Aljabar lintasan yang diperumum oleh Leavitt pada graf perluasan dan memenuhi relasi Cuntz-Krieger disebut dengan aljabar lintasan Leavitt (Leavitt path algebra). Dari sini juga dapat dikatakan bahwa aljabar lintasan merupakan sub-aljabar dari aljabar lintasan Leavitt yang elemennya dibangun dari lintasan-lintasan yang hanya memuat garis nyata.

Aljabar lintasan dan aljabar lintasan Leavitt mempunyai beberapa sifat yang sama, diantaranya keduanya merupakan $K$-aljabar asosiatif dan merupakan aljabar bertingkat. Lebih khusus aljabar lintasan Leavitt merupakan Z-aljabar bertingkat. Akan tetapi, aljabar lintasan dan aljabar lintasan Leavitt juga mempunyai beberapa perbedaan. Salah satu diantaranya adalah tentang sifat semiprima yang melekat pada keduanya. Untuk sebarang graf $E$ aljabar lintasan Leavitt pada $E$ adalah semiprima. Tetapi hal ini tidak selalu berlaku untuk aljabar lintasan. Di dalam tulisan ini juga dibahas mengenai sokel pada ring yang berkaitan erat dengan sifat semiprima pada aljabar lintasan Leavitt.

\section{METODE PENELITIAN}

Pertama-tama sebagai motivasi untuk mempelajari aljabar lintasan Leavitt semiprima dibutuhkan pengertian dasar mengenai ring prima dan semiprima. Untuk mempelajarinya digu-nakan buku Hungerfold (1984)[11]. Selanjutnya untuk mempelajari aljabar lintasan dan aljabar lintasan Leavitt diperlukan pengetahuan tentang aljabar secara umum. Untuk mempelajarinya digunakan buku Fraleigh (2000)[4], Wisbauer (1996)[10] dan Adkins (1992)[12]. Dalam pembahasan lebih lanjut, aljabar lintasan dan aljabar lintasan Leavitt merupakan aljabar bertingkat. Untuk itu diperlukan juga pengetahuan tentang aljabar bertingkat yang dikaji dalam buku Dummit (2004)[3], Wisbauer (1991)[10] dan Rotman (2002)[9]. Dalam tulisan ini akan dibahas juga mengenai elemenelemen dari aljabar yang mempunyai sifat khusus, antara lain elemen idempoten, idempoten ortogonal, primitif, elemen satuan, dan elemen unit lokal. Pengertian dari elemenelemen dengan sifat khusus tersebut dipelajari dari buku Dummit (2004)[3] dan Assem (2006)[1].

Graf sebagai representasi aljabar dan sifat-sifatnya yang berhubungan dengan sifat grafnya dikaji dalam 
Assem (2006)[1]. Himpunan lintasan dalam suatu graf, secara struktur merupakan semigrup terhadap perkalian. Hal ini dipelajari dari Fraleigh (2000)[4]. Kemudian mengenai graf perluasan yang dilakukan Leavitt banyak dikaji dalam paper yang disusun oleh Abrams dan Aranda Pino $(2005,2006)[8]$. Selain itu Aranda Pino dan Pardo (2008)[7] juga membahas aljabar lintasan Leavitt sebagai aljabar bertingkat.

Pembahasan lebih lanjut mengenai jumlahan dari ideal kiri minimal atau yang lebih dikenal dengan sokel, yang dipelajari oleh Dangerfield(2011)[2], Martin dan Aranda Pino (2008)[6], Siles Molina (2008)[5]. Sedangkan pembaha-san mengenai sifat-sifat semiprima pada aljabar lintasan dan aljabar lintasan Leavitt terdapat di paper Aranda Pino (2008)[5].

\section{HASIL DAN PEMBAHASAN}

\subsection{ALJABAR LINTASAN}

Dalam bagian ini akan diperkenalkan mengenai aljabar lintasan, beserta contoh dan sifat-sifatnya.

\section{Definisi}

$$
\text { 3.1.1. }
$$

Graf $E=\left(E^{0}, E^{1}, r, s\right)$ terdiri atas dua himpunan-himpunan berhingga $E^{0}, E^{1}$ dan fungsi-fungsi $\quad r, s: E^{1} \rightarrow E^{0}$. Anggota-anggota dari $E^{0}$ dinamakan titik-titik dan anggota-anggota dari $E^{1}$ dinamakan garis-garis.

\section{Graf $E$ dikatakan row-finite} graph (graf baris-berhingga) jika $s^{-1}(v)$ himpunan berhingga untuk setiap $v \in E^{0}$. Dari sini tampak bahwa jika himpunan garis $E^{0}$ berhingga maka himpunan $E^{1}$ juga berhingga. Selanjutnya dikatakan graf $E$ berhingga jika $E^{0}$ berhingga. Jadi, yang dimaksud graf berhingga dalam paper ini adalah row-finite graph.

Definisi 3.1.2. Sebuah lintasan (path) $\mu$ dalam graf $E$ adalah barisan garisgaris $\mu=e_{1} e_{2} \ldots e_{n}$ sedemikian sehingga $r\left(e_{i}\right)=s\left(e_{i+1}\right)$ untuk $i=1,2, \ldots, n-1$. Selanjut-nya $s(\mu)=s\left(e_{1}\right)$ dinamakan source (sumber/pangkal) dari $\mu$, $r(\mu)=r\left(e_{n}\right)$ dinamakan range (bayangan/ujung) dari $\mu$ dan $n$ adalah Panjang lintasan dari $\mu$, diberi simbol $l(\mu)=n$.

Dinotasikan $\mu^{0}$ sebagai himpunan dari semua titik-titik dengan $\mu^{0}=$ $\left\{s\left(e_{1}\right), r\left(e_{i}\right) ; i=1,2, \ldots, n\right\}$. Himpunan dari semua lintasan-lintasan dalam graf $E$ dinotasikan sebagai $E^{*}$.

Misalkan ada suatu graf berarah $E=\left(E^{0}, E^{1}, r, s\right)$ dan lintasan $\mu=$ 
$e_{1} e_{2} \ldots e_{n} . \quad$ Jika $\quad s(\mu)=s\left(e_{1}\right)=v \quad$ dan $r(\mu)=r\left(e_{n}\right)=w$ untuk setiap $v \in E^{0}$, maka $v$ disebut emit (memancarkan) $\mu$ dan $w$ menerima $\mu$. Titik $v$ disebut tenggelam (sink) jika $\mathrm{V}$ tidak memancarkan sebarang garis, atau bisa dikatakan:

$$
\text { ( } \left.v \text { tenggelam } \Leftrightarrow v \neq s(e), \forall e \in E^{1}\right) .
$$

$$
\text { Setiap titik } v \in E^{0} \text {, }
$$

diasosiasikan dengan lintasan dengan panjang 0 , sedangkan sebarang garis $e \in E^{1}$, diasosiasikan dengan lintasan dengan panjang 1 . Untuk selanjutnya yang dimaksud sebarang graf dalam paper ini adalah row-finite graph.

Berikut ini adalah contoh graf yang dimaksud

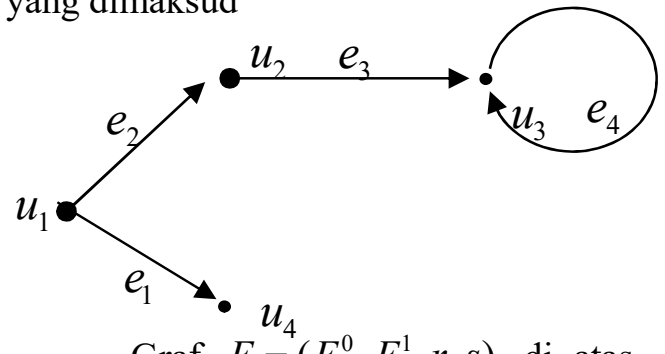

Graf $E=\left(E^{0}, E^{1}, r, s\right)$ di atas

terdiri dari himpunan:

1) $E^{0}=\left\{u_{1}, u_{2}, u_{3}, u_{4}\right\}$

2) $E^{1}=\left\{e_{1}, e_{2}, e_{3}, e_{4}\right\}$

Dapat dilihat bahwa

$s\left(e_{1}\right)=u_{1}, r\left(e_{1}\right)=u_{4}, s\left(e_{2}\right)=u_{1}$, $r\left(e_{2}\right)=u_{2}$, dan seterusnya. Titik $u_{4}$ ada-lah $\sin k$, karena $u_{4} \neq s(e), \forall e \in E^{1}$. Contoh-contoh lintasan (path) dari graf di atas adalah $u_{1} u_{2} u_{3}, u_{1} u_{4}, e_{1}, e_{2} e_{3}, e_{4}, e_{4} e_{4}, e_{2} e_{4} e_{4}$ dan seterusnya, sejumlah tak berhingga banyak lintasan. Untuk lintasan $\mu=e_{2} e_{3} e_{4}{ }^{3}$ maka $\mu^{0}=\left\{u_{1}, u_{2}, u_{3}\right\}$.

Di dalam juga didefinisikan suatu perkalian dua lintasan sebagai berikut.

Definisi 3.1.3. Diberikan Graf berarah $E=\left(E^{0}, E^{1}, r, s\right) \quad$ dan lintasan $\mu=e_{1} e_{2} \ldots . . e_{m}, \quad v=f_{1} f_{2} \ldots . . f_{n}$. Operasi perkalian sebarang dua lintasan $\mu=e_{1} e_{2} \ldots . e_{m} \quad$ dan $\quad v=f_{1} f_{2} \ldots . . f_{n}$ Didefinisikan sebagai $\mu v=e_{1} e_{2} \ldots . . e_{m}$ $f_{1} f_{2} \ldots . . f_{n} \quad j i k a r(\mu)=s(v) \quad$ dan $\mu v=0 j i k a r(\mu) \neq s(v)$.

Dari definisi perkalian inilah dapat digunakan untuk mendefinisikan aljabar lintasan Leavitt. Dalam mendefinisikan aljabar lintasan dari suatu graf $E$ diperlukan operasi perkalian lintasan seperti definisi diatas, sebagai berikut:

Definisi 3.1.4. Diberikan lapangan $K$ dan graf $E$. Didefinisikan aljabar lintasan pada graf $E$ atas lapangan $K$ sebagai $K$-aljabar yang bebas (free) dalam lintasan KE dengan basis himpunan lintasan-lintasan dalam $E$ 
dan memenuhi syarat : $v_{i} v_{j}=\delta_{i j} v_{i}$ untuk $\forall v_{i}, v_{j} \in E^{0}$ dan $e_{i}=e_{i} r\left(e_{i}\right)=s\left(e_{i}\right) e_{i}$ dengan

$$
K E=\{\alpha
$$

$\left.\alpha=\sum_{x \in E} a_{x} x, a_{x} \in K\right\}$, dimana graf $E$

dapat dipandang sebagai semigrup multiplikasi, sehingga KE merupakan K-aljabar.

Contoh graf yang merupakan aljabar lintasan adalah sebagai berikut

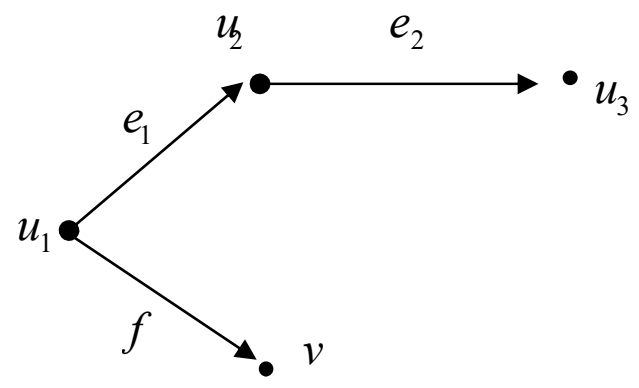

\subsection{ALJABAR LINTASAN}

LEAVITT

Aljabar lintasan pada graf $E$, belumlah cukup untuk mendefinisikan aljabar lintasan Leavitt. Definisi aljabar lintasan Leavitt membutuhkan graf $E$ yang diperluas atau perluasan graf (extended graph), yang didefinisikan sebagai berikut:

Definisi 3.2.1. Diberikan graf $E$, didefinisikan perluasan graf $E$ (extended graphof $E$ ) sebagai graf baru yang ditulis $\hat{E}=\left(E^{0}, E^{1} \cup\left(E^{1}\right)^{*}, r^{\prime}, s^{\prime}\right)$ dengan
$\left(E^{1}\right)^{*}=\left\{e_{i}^{*} \mid e_{i} \in E^{1}\right\}$ dan fungsi $r^{\prime}$ dan s'yang didefinisikan :

$$
\begin{aligned}
& \left.r^{\prime}\right|_{E^{1}}=r,\left.s^{\prime}\right|_{E^{1}}=s, r^{\prime}\left(e_{i}^{*}\right)=s\left(e_{i}\right), \\
& \operatorname{dan} s^{\prime}\left(e_{i}^{*}\right)=r\left(e_{i}\right)
\end{aligned}
$$

Selanjutnya diberikan contoh untuk memperjelas perluasan pada graf, sebagai berikut.

Contoh 3.2.2. Diberikan perluasan graf sebagai berikut

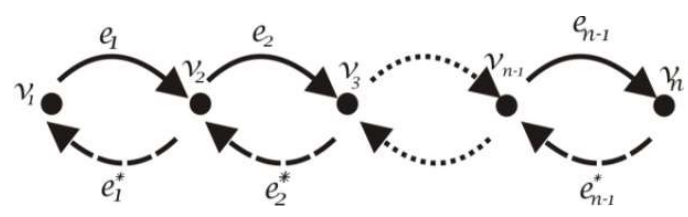

Gambar graf diatas adalah graf yang terdiri dari himpunan-himpunan

$E^{0}=\left\{v_{1}, v_{2}, \ldots, v_{n}\right\}$,

$E^{1}=\left\{e_{1}, e_{2}, \ldots, e_{n-1}\right\}$

$\left(E^{1}\right) *=\left\{e_{1}^{*}, e_{2}^{*}, \ldots, e_{n-1}^{*}\right\}$, yang

disebut garis nyata adalah $\left\{e_{1}, e_{2}, \ldots, e_{n-1}\right\}$, sedangkan garis-garis hantu adalah $\left\{e_{1}^{*}, e_{2}^{*}, \ldots, e_{n-1}^{*}\right\}$ dengan $s\left(e_{1}\right)=v_{1}=r\left(e_{1}\right)^{*}, s\left(e_{2}\right)=v_{2}=r\left(e_{2}\right) *$ dan seterusnya.

Selanjutnya akan diberikan definisi aljabar lintasan Leavitt beserta beberapa contoh sebagai ilustrasi untuk mengupas sifat-sifatnya

Definisi 3.2.3. Diberikan lapangan $K$ dan graf berhingga $E$ (E row-finite 
graph). Aljabar lintasan Leavitt dari E dengan koefisien dalam lapangan $K$ didefinisikan sebagai aljabar lintasan pada graf perluasan $\hat{E}$, yang memenuhi relasi :

((CK1)) $e^{*} f=\delta_{e f} r(e)$ untuk setiap

$$
e, f \in E^{1}
$$

$((C K 2)) \quad v=\sum_{\left(e \in E^{1} ; s(e)=v\right)} e e^{*} \quad$ untuk setiap $v \in E^{0}$ dengan $v$ bukan sink.

Aljabar lintasan Leavitt ini, selanjutnya dinotasikan dengan $L_{K}(E)$ atau lebih umum dengan $L(E)$. Kondisi ((CK1)) dan ((CK2)) dinamakan relasi Cuntz-Kreager . Secara khusus, kondisi ((CK2)) adalah syarat Cuntz-Kreager pada vyang bukan sink, artinya ada $e \in E^{1}$ sedemikian sehingga $v=s(e)$. Dengan kata lain, jika vsinkmakatidak memiliki relasi ((CK2)) pada $v$.

Contoh 3.2.4. Diberikan graf $E$ yang terdiri atas $E^{0}=\{v\}, E^{1}=\{e\}$, artinya graf yang terdiri dari satu titik dan satu garis, sebagaimana graf yang diperlihatkan dalam gambar berikut:

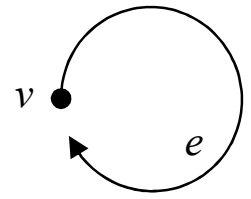

Lemma 3.2.5. Setiap monomial dalam aljabar lintasan Leavitt $L(E)$ berbentuk:

(i) $k v$ dengan $k \in K$ dan $v \in E^{0}$; atau

(ii) $k e_{i_{1}} \ldots e_{i_{\sigma}} e_{j_{1}}^{*} \ldots e_{j_{\tau}}^{*}$ dimana

$$
\begin{aligned}
& k \in K ; \sigma, \tau \geq 0, \sigma+\tau>0 ; \\
& e_{i_{s}} \in E^{1} \text { dan } e_{i_{t}} \in\left(E^{1}\right)^{*}
\end{aligned}
$$

untuk $0 \leq s \leq \sigma, 0 \leq t \leq \tau$

Lemma 3.2.6. Diberikan graf $E$, lapangan $K$ danaljabar lintasan Leavitt $L(E)$ atas lapangan $K . . L(E)$ merupakan Z-aljabar bertingkat (Zgraded algebra), dengan derajat yang dinyatakan oleh:

$\operatorname{deg}(v)=0$ untuk setiap $v \in E^{0} ; \operatorname{deg}(e)=1$ dan $\operatorname{deg}\left(e^{*}\right)=-1$ untuk setiap $e \in E^{1}$. Hal ini berarti bahwa $L(E)=$ $\bigoplus_{n \in Z} L(E)_{n}, \quad$ dimana $L(E)_{0}=K E+A_{0} \quad$ dan $\quad L(E)_{n}=A_{n}$ untuk $n \neq 0$, dengan

$$
A_{n}=\sum k e_{i_{1}} \ldots e_{i_{\sigma}} e_{j_{1}}^{*} \ldots e_{j_{\tau}}^{*}: \sigma+\tau>0,
$$$$
e_{i_{s}} \in E^{1}, e_{j_{t}}^{*} \in E^{1 *}, k \in K, \sigma-\tau=n
$$

atau ekuivalen

$$
\begin{array}{r}
L(E)_{n}=\operatorname{span}\left\{p q^{*} \mid p, q \in E^{*},\right. \\
l(p)-l(q)=n, \forall n \in Z\} .
\end{array}
$$


3.3. SIFAT SEMIPRIMA PADA ALJA-BAR LINTASAN LEAVITT

Aljabar lintasan dan aljabar lintasan Leavitt mempunyai beberapa sifat yang sama, diantaranya keduanya merupakan $K$-aljabar asosiatif dan merupakan aljabar bertingkat. Lebih khusus aljabar lintasan Leavitt merupakan Z-aljabar bertingkat. Akan tetapi, Aljabar lintasan dan aljabar lintasan Leavittjuga mempunyai beberapa perbedaan. Salah satu diantaranya adalah tentang sifat semiprima yang melekat pada keduanya. Untuk sebarang graf $E$ aljabar lintasan Leavitt pada $E$ adalah semiprima.Tetapi hal ini tidak selalu berlaku untuk aljabar lintasan. Sebelum membahas sifat tersebut, terlebih dahulu dibahas mengenai teori sokel pada ring yang berkaitan erat dengan sifat semiprima pada aljabar lintasan Leavitt.

\section{3a. SOKEL PADA RING}

Dalam mempelajari sokel pada ring dibutuhkan pengertian mengenai ideal minimal yang didefinisikan sebagai berikut.

Definisi 3.3a.1. Diberikan ring $R$. Himpunan $L$ dikatakan ideal kiri minimal dari $R$ jika $L \neq\{0\}$ dan untuk setiap Kideal kiri di $R, \quad j i k a$
$0 \subset K \subset L$ maka $K=0$ atau $K=L$. Sedangkan himpunan $L$ dikatakan ideal kanan minimal dari $R$ jika $L \neq\{0\}$ dan untuk setiap Kideal kanan di $R$, jika $0 \subset K \subset L$ maka $K=0$ atau $K=L$. Jika memenuhi ideal kiri minimal dan ideal kanan minimal disebut sebagai ideal minimal.

Dari definisi diatas jelas bahwa suatu ideal dikatakan ideal minimal jika ideal tersebut bukan ideal nol dan tidak memuat ideal non-trivial selain dirinya sendiri. Untuk lebih jelasnya, diberikan contoh sebagai berikut.

Contoh 3.3a.2. Jika ring $R$ merupakan lapangan, maka ideal minimal dari ring $R$ adalah $R$ itu sendiri. Hal ini dikarenakan ideal-ideal di lapangan $R$ hanya $\{0\}$ dan $R$ itu sendiri, dengan ideal nontrivialnya adalah $R$.

Selanjutnya didefinisikan tentang jumlahan dari keluarga ideal kiri atau ideal kanan minimal, sebagai berikut.

Definisi 3.3a.3. Diberikan ring $R$. Sokel kiri dari $R$ (dinotasikan sebagai $\operatorname{Soc}_{l}(R)$ adalah jumlahan dari keluarga ideal kiri minimal di $R$ (ideal nol jika $R$ bukan ideal kiri minimal). Sokel kanan dari $R$ (dinotasikan sebagai $\operatorname{Soc}_{r}(R)$ ) adalah jumlahan dari keluarga idealkanan minimal di $R$ 
(ideal nol jika $R$ bukan ideal kanan minimal)..

Dari definisi diatas, jika $s \in \operatorname{Soc}_{l}(R)$ maka dapat ditulis $s=\sum_{i} l_{i}, \forall 0 \neq l_{i} \in L_{i}$ untuk berhingga banyak $i$ dan $L_{i}$ ideal kiri minimal dari $R$.

Proposisi 3.3a.4. Jika $R$ adalah ring semiprima, maka Soc $_{l}(R)=\operatorname{Soc}_{r}(R)$.

\section{3b. SIFAT SEMIPRIMA PADA} ALJABAR LINTASAN DAN ALJABAR LINTASAN LEAVITT

Dalam bagian ini, akan dibahas mengenai aljabar lintasan semiprima dan aljabar lintasan leavitt semiprima serta sifat-sifat yang berlaku di dalamnya. Disertakan pula beberapa contoh sebagai pendukung teori yang disajikan.

Definisi 3.3b.1. Diberikan graf $E$ dan lapangan K. Aljabar lintasan KE disebut semiprima jika untuk setiap $\mu \in K E$ dengan $\mu K E \mu=0 \quad$ maka $\mu=0$

Kemudian diberikan proposisi yang berkaitan dengan sifat semiprima pada aljabar lintasan, sebagai berikut:

Proposisi 3.3b.2. Diberikan graf E dan lapangan K. Aljabar lintasan KE disebut semiprima jika dan hanya jika untuk setiap lintasan $\mu \in K E_{a d a}$ sebuah lintasan $\mu^{\prime} \in K E_{\text {sedemikian }}$ sehingga $\quad s\left(\mu^{\prime}\right)=r(\mu)$ dan $s(\mu)=$ $r\left(\mu^{\prime}\right)$.

Setelah membahas semiprima di aljabar lintasan $K E$, akan dibandingkan sifat semiprima di aljabar lintasan dengan aljabar lintasan Leavitt sebagai berikut: Akan ditunjukkan bahwa tidak seperti di aljabar lintasan $K E$, bahwa untuk sebarang graf pada aljabar lintasan Leavitt $L_{K}(E)$ adalah semiprima. Untuk menunjukkannya, kita perlu beberapa definisi sebagai berikut

Definisi 3.3b.3. Garis e disebut garis keluar (exit) untuk suatu lintasan $\mu=e_{1} e_{2} \ldots e_{n}$, jika ada $i$ sedemikian sehingga $s(e)=s\left(e_{i}\right)$ dan $e \neq e_{i}$. Garis e disebut garis masuk (resp. entrance) untuk suatu lintasan $\mu=e_{1} e_{2} \ldots e_{n}$, jika ada isedemikian sehinggar $(e)=r\left(e_{i}\right)$ dan $e \neq e_{i}$. Jika c merupakan lintasan yang memuat sikel dengan $s(c)=r(c)=v \quad$ maka $c$ disebut basis (based) div.

Untuk memperjelas definisi diatas diberikan contoh sebagai berikut.

Contoh 3.3b.4. Diberikan graf $E$ seperti gambar dibawah ini 


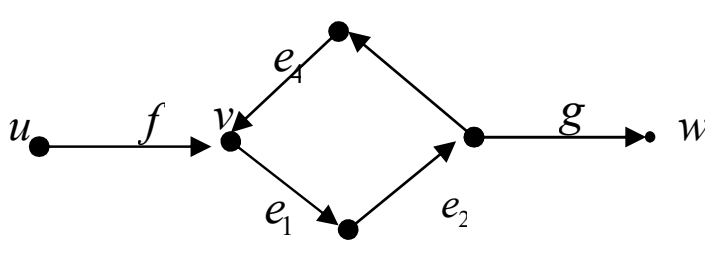

Jika diberikan lintasan $c=e_{1} e_{2} e_{3} e_{4}$, maka $c$ merupakan sikel di $E$ dengan basis di $v$. Garis $g$ merupakan garis keluar dari lintasan $c$ dan garis $f$ merupakan garis masuk dari lintasan $c$.

Selanjutnya diberikan yang berkaitan dengan relasi yang ada di dalam lintasan suatu graf, sebagai berikut

Definisi 3.3b.5. Diberikan Graf berarah $E=\left(E^{0}, E^{1}, r, s\right) \quad$ dan lintasan $\mu=e_{1} e_{2} \ldots e_{n}$. Didefinisikan suatu relasi $\geq d i \quad E^{0}$,jika $v \geq w$ maka ada lintasan $\mu \in E^{*}$ dengan $s(\mu)=v$ dan $r(\mu)=w$. Suatu pohon dari titik $v \in E^{0}$ didefinisikan sebagai $T(v)=\left\{w \in E^{0} \mid v \geq w\right\}$.

Contoh 3.3b.6.Diberikan graf $E$ seperti gambar dibawah ini:

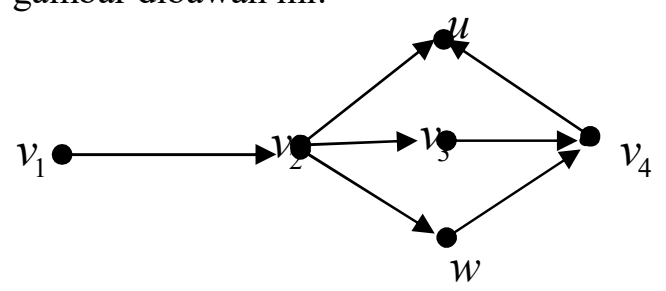

Dari graf diatas yang disebut sebagai pohon dari titik $v_{1} \in E^{0}$ adalah
$T\left(v_{1}\right)=E^{0}$. Sedangkan pohon dari titik $w \in E^{0}$ adalah $\left\{w, v_{4}, u\right\}$.

Pendefisian semiprima pada aljabar lintasan memotivasi untuk mendefinisikan semiprima pada aljabar lintasan Leavitt, sebagai berikut.

Definisi 3.3b.7. Diberikan graf $E$ dan lapangan K. Aljabar lintasan leavitt $L_{K}(E)$ disebut semiprima jika untuk setiap $\mu \in L_{K}(E)$ dengan $\mu L_{K}(E) \mu=0$ maka $\mu=0$.

Sebelum membuktikan bahwa setiap aljabar lintasan Leavitt $L_{K}(E)$ merupakan semiprima terlebih dahulu dibuktikan beberapa lemma dan proposisi yang mendukung pembuktian tersebut, diantaranya:

Proposisi3.3b.8. Diberikan graf E dan lapangan K. Aljabar lintasan Leavitt $L_{K}(E)$ semiprima jika dan hanya jika untuk setiap lintasan $\mu \in L_{K}(E)$ ada sebuah lintasan $\mu^{\prime} \in L_{K}(E)$ sedemikian sehingga $s\left(\mu^{\prime}\right)=r(\mu)$ dan $s(\mu)=r\left(\mu^{\prime}\right)$

Selanjutnya diberikan suatu lemma yang berkaitan isomorfisma dari suatu $K$-aljabar, sebagai berikut:

Lemma 3.3b.9. Diberikan sebarang graf E. Jika diberikan garis $v$ 
sedemikian sehingga ada sikel tanpa garis keluar c dengan basis di v, maka:

$$
\begin{aligned}
v L_{K}(E) v & =\left\{\sum_{i=-m}^{n} k_{i} c^{i} \mid k_{i} \in K ; m, n \in N\right\} \\
& \cong K\left[x, x^{-1}\right] .
\end{aligned}
$$

Dimana $\cong$ menyatakan isomorfisma dari K-aljabar dan memenuhi $c^{0}=w$ dan $c^{-t}=\left(c^{*}\right)^{t}$ untuk setiap $t \geq 1$.

Selanjutnya diberikan suatu proposisi mengenai komposisi antara suatu elemen di dalam aljabar lintasan Leavitt dengan lintasan dalam suatu graf.

Proposisi 3.3b.10. Diberikan sebarang graf E. Untuk setiap elemen tak nol $x \in L_{K}(E)$, ada lintasan

$\mu_{1} \mu_{2} \ldots \mu_{r} v_{1} v_{2} \ldots v_{s} \in E^{0} \cup E^{1} \cup\left(E^{1}\right)^{*}$ sedemikian sehingga:

1. $\mu_{1} \mu_{2} \ldots \mu_{r} x v_{1} v_{2} \ldots v_{s}$ adalah elemen tak nol di Kv, untuk suatu $v \in E^{0}$, atau

2. Ada sebuah titik $w \in E^{0} d a n$ sikel tanpa garis keluar dengan basis di $w$ sedemikian sehingga $\mu_{1} \mu_{2} \ldots \mu_{r} x v_{1} v_{2} \ldots v_{s}$ adalah elemen tak nol di $w L_{K}(E) w$.

Kasus keduanya tidak saling terpisah.

Selanjutnya akan dibuktikan bahwa sebarang graf merupakan aljabar lintasan Leavitt, yaitu sebagai berikut:
Proposisi 3.3b.11. Untuk sebarang graf E maka $L_{K}(E)$ adalah semiprima.

\section{Bukti:}

Ambil sebarang ideal tak nol $I_{v}:=\sum\left\{k \alpha \beta^{*} \mid \alpha, \beta \in E^{*}, r(\alpha)=v=r(\beta)\right.$, $k \in K\}$ yang merupakan ideal di $L_{K}(E)$ sedemikian sehingga $I_{v}^{2}=0$. Akan dibuktikan bahwa $I_{v}=0$. Jika $I_{v}$ hanya terdiri dari sebuah titik maka $I_{v}=0$, bukti selesai. Tetapi jika ada elemen tak nol $p\left(c, c^{*}\right) \in I_{v}$ sedemikian sehingga $p\left(c, c^{*}\right)^{2}=0$, maka $p\left(c, c^{*}\right)$ dapat ditulis sebagai $p\left(c, c^{*}\right)=\sum k \alpha \beta^{*}$. Andaikan $I_{v} \neq 0 \quad$ maka ada $p\left(c, c^{*}\right) \neq 0 \quad$ sedemikian sehingga $p\left(c, c^{*}\right)^{2}=0 \Rightarrow\left(\sum k \alpha \beta^{*}\right)^{2}=0$ dengan $\alpha \beta^{*} \neq 0$, pastilah diperoleh $k=0$. Timbul kontradiksi dengan $p\left(c, c^{*}\right) \neq 0$, jadi yang benar $I_{v}=0$.

Dapat dibuktikan juga dengan mengambil $o \neq x \in L_{K}(E)_{0} \quad$ dengan $x L_{K}(E) x=0$ akan dibuktikan $x=0$. Jika $x$ merupakan kombinasi linear dari himpunan garis-garis, maka $x=\sum_{i=1}^{n} k_{i} v_{i}$ untuk setiap $v_{i} \in E^{0}$. Akibatnya $0 \neq v x v \in L_{K}(E)_{n}, \quad$ untuk itu $x$ adalah kombinasi linear dari garis-garis dan merupakan monomial $a b *$ dengan $a$ 
dan $b$ adalah lintasan-lintasan dengan derajat positif yang $\operatorname{sama}(l(a)=l(b))$. Dengan menggunakan CK2, maka untuk setiap garis $w \in E^{0} \quad$ yang tidak tenggelamdan memunculkan $x$, dapat ditulis dengan $\sum_{\left\{e_{i} \in E^{1} \mid s\left(e_{i}\right)=w\right\}} e_{i} e_{i}{ }^{*}$. Sehingga $x$ dapat ditulis sebagai penujmlahan dari monomial-monomial berderajat 0 sedemikan sehi-ngga hanya ada satu garis yang merupakan titik tenggelam. Dengan kata lain, $x=x_{1}+x_{2}, \quad$ dengan $\quad x_{1} \quad$ adalah kombinasi linear dari garis-garis dengan derajat 0 dan $x_{2}$ adalah kombinasi linear dari tenggelam.

Sekarang, anggap bahwa satu dari monomial-monomial $a b$ * merupakan kombinasi linear dari $x_{1}$ dengan derajat maksimum di $a$. Dapat ditulis sebagai $a=f a^{\prime}, b=g b^{\prime}$ dengan $f, g \in E^{1} \quad$ dan $\quad a^{\prime}, b^{\prime} \quad$ merupakan lintasan-lintasan dengan derajat sama. Akibatnya $x_{1}$ dapat ditulis sebagai $x_{1}=f x^{\prime} g *+z$ dengan $x^{\prime} \in L(E) \backslash\{0\}, z \in L(E)_{n} \quad$ dan $\quad f^{*} z g=0$, hal ini karena $x_{1}$ hanya terdiri atas elemen-elemen dengan derajat 0 yang bukan garis. Dan karena $x_{2}$ hanya terdiri dari titik tenggelamsehingga kita punya:

$$
\begin{aligned}
f^{*} x g & =f^{*} x_{1} g+f^{*} x_{2} g \\
& =f^{*}\left(f x^{\prime} g^{*}+z\right) g+f^{*} x_{2} g \\
& =f^{*} f x^{\prime} g^{*}+f^{*} z g+f^{*} x_{2} g \\
& =x^{\prime}+0+0=x^{\prime}
\end{aligned}
$$

yang merupakan elemen tak nol di $L_{K}(E)_{n}$. Akibatnya $L_{K}(E)_{n}$ terdiri atas kombinasi linear tak nol dari garis-garis. Andaikan $L_{K}(E)_{n}$ tidak terdiri atas elemen-elemen homogen dengan derajat $<l$ dan akan dibuktikan bahwa $L_{K}(E)_{n}$ tidak terdiri atas elemen-elemen homogen dengan derajat $l$. Anggap bahwa $0 \neq x \in L_{K}(E)_{n} \cap L_{K}(E)_{l}$. Untuk setiap $f \in E^{1}$ berlaku $f^{*} x \in L_{K}(E)_{n}$ yang merupakan elemen homogen dengan derajat $<l$. Maka $f^{*} x=0$ untuk setiap $f \in E^{1}$. Dengan menggunakan $\mathrm{CK} 2$ berakibat $f f * x=v x=0$ untuk setiap $\quad v \in E^{0}$ sedemikian sehingga $s^{-1}(v) \neq \varnothing$. Dengan kata lain jika $v \in E^{0}$ dengan $s^{-1}(v)=\varnothing$ maka untuk setiap $g \in E^{1}$ kita punya $v g=v(g) g=0 \quad$ dengan $\quad v \neq s(g)$. sehingga $v x=0$ untuk setiap $v \in E^{0}$ berakibat $\quad x=0$. Dan karena $\left(L_{K}(E)^{*}=L_{k}(E)_{-n}, \quad \forall n \in N, \quad\right.$ ini menunjukkan bahwa $L_{K}(E)_{n}$ tidak terdiri dari elemen-elemen homogen dengan derajat negatif.

Syarat perlu dan cukup suatu graf dikatakan aljabar lintasan 
semiprima adalah untuk setiap lintasan $\mu \in L_{K}(E)$ ada sebuah lintasan $\mu^{\prime} \in L_{K}(E)$ sedemikian sehingga $s\left(\mu^{\prime}\right)=r(\mu)$ dan $s(\mu)=r\left(\mu^{\prime}\right)$

Kemudian diberikan suatu akibat dari Proposisi 3.3b.11, sebagai berikut.

Akibat 3.3b.12. Untuk sebarang graf E $\operatorname{maka~Soc}_{l}\left(L_{K}(E)\right)=\operatorname{Soc}_{r}\left(L_{K}(E)\right)$.

Dari sini membuktikan bahwa untuk sebarang graf maka aljabar lintasan Leavitt bersifat semiprima. Dimana sokel kiri dari aljabar lintasan leaviit sama dengan sokel kanan dari aljabar lintasan Leavittnya

\section{KESIMPULAN}

Berdasarkan pembahasan diatas dapat disimpulkan bahwa aljabar lintasan dan aljabar lintasan Leavitt mempunyai beberapa sifat yang sama, diantaranya:

1. Keduanya merupakan $K$-aljabar asosiatif.

2. Keduanya merupakan aljabar bertingkat. Lebih khusus aljabar lintasan Leavitt merupakan Z-aljabar bertingkat.

3. Himpunan lintasan-lintasan yang berbeda membentuk himpunan yang bebas linier.
4. Aljabar lintasan merupakan sub-aljabar dari aljabar lintasan Leavitt yang elemennya dibangun dari lintasan-lintasan yang hanya memuat garis nyata.

Selain mempunyai kesamaan sifat, aljabar lintasan dan aljabar lintasan Leavitt mempunyai perbedaan sifat, salah satu diantaranya mengenai sifat semiprima yang melekat pada keduanya. Untuk sebarang graf maka aljabar lintasan Leavitt bersifat semiprima. Akan tetapi hal ini tidak selalu berlaku pada sebarang graf di aljabar lintasan. Karena alasan semiprima inilah, dapat disimpulkan bahwa untuk sebarang graf pada aljabar lintasan Leavitt berlaku jumlahan dari setiap ideal kiri minimal sama dengan jumlahan dari ideal kanan minimal.

\section{REFERENSI}

[1]. I.Assem, D. Simson, A. Skowronski, Elemens of the Repre-sentation Theory of AssociativeAlgebras, London Math. Soc. Student Text 65, Cambridge University Press, 2005.

[2]. D. Iain, Leavitt path algebra, a thesis submitted for the degree of master science, Otago University, New Zealand, 2011. 
[3]. D. S. Dummit, R. M. Foote, Abstract Algebra, United Stated Third Edition, University of Vermont, 2004.

[4]. Fraleigh, John. B, 2000, A First Course in Abstract Algebra,Sixth Edition, Addition-Wesley Puplising Compeny, Inc,

[5]. G. Aranda Pino, D. Martin Barquero, C. Martin Gonzalez, M, Siles Molina, Socle theory for Leavitt path algebras of arbitrary graphs Rev. Mat. Iberoamericana (to appear)(2008).

[6].G. Aranda Pino, D. Martin Barquero, C. Martin Gonzalez, M, Siles Molina , The socle of a Leavitt path algebra, J. Pure Appl. Algebra 212(3) (2008), 500509.

[7]. G. Aranda Pino, Pardo, E., 2008, Stable rank of Leavitt path algebras, Proc. Amer. Math. Soc., 136 no. 7, 2375-2386.

[8]. M. Siles Molina, Algebras of quotients of path algebras, J. Algebra 319 (12) (2008), 329-348.

[9].Rotman J., 2003, Advanced Modern Algebra, Prentice Hall, New York .
[10]. Wisbauer, Robert, 1991, Foundation of Module and Ring Theory, University of Dusseldorf, Dusseldorf

[11]. Hungerford, T. W, Graduete Text in Mathematics Algebra, Springer Verlag, New York, Heidelberg Berlin, 1984.

[12]. Adkins, Algebra An Approach via Module Theory, Springer-Verlag, 1992 